\title{
PARTISIPASI POLITIK MASYARAKAT PEDESAAN DALAM PEMILIHAN GUBERNUR JAWA TENGAH TAHUN 2008 \\ (Studi Kasus mengenai Partisipasi Politik Masyarakat Pedesaan di Kecamatan \\ Karanggede, Boyolali dalam Pilgub Jateng 2008)
}

\author{
Sri Herwindya Baskara Wijaya \\ (r_windya@yahoo.com) \\ Dosen Jurusan Ilmu Komunikasi Universitas Semarang
}

\section{Abstract}

Every citizen has interest and preference on who should command him/her and on the public policy. The directly election of local leader is part of citizen contribution to the public policy corresponding to the Act No. 32 of 2004 about Local Government. That the governor and vice governor position is not based on the election mechanism by $D P R D$ like the previous age. Thus, the society is political participation has a very important role here. Based on the result of research shows that generally, the rural society in subdistrict Karanggede Boyolali has the lower participation level in the Central Java's Governor of 2008.

Keywords: public policy, political participation, direct election

\section{Pendahuluan}

Pemilihan Gubernur (Pilgub)

Jawa Tengah (Jateng) Tahun 2008 baru saja selesai. Pilkada provinsi tersebut digelar 22 Juni 2008. Ada lima pasangan calon gubernur (Cagub) dan calon wakil gubernur (Cawagub) yang bertarung pada Pilgub tersebut, antara lain Bambang Sodono-Muh Adnan yang didukung Partai Golkar, Agus Soeyitno-Abdul Kholiq Arif yang didukung Partai Kebangkitan Bangsa (PKB), Sukawi Sutarip-Sudharto yang didukung Partai Demokrat (PD) dan Partai Keadilan Sejahtera (PKS), Bibit Waluyo-Rustriningsih yang didukung Partai Demokrasi Indonesia Perjuangan (PDIP) dan Muh Tamzil-Abdul Rozaq Rais yang disokong Partai Persatuan Pembangunan (PPP) dan Partai Amanat Nasional (PAN).

Suksesnya Pilgub yang digelar tidak bisa dilepaskan dari peran serta rakyat. Rakyat adalah pemilik suara yang tentu diperebutkan oleh para kandidat yang berkompetisi. Di sinilah arti penting partisipasi politik masyarakat dalam ajang pemilihan tersebut. Begitu pula halnya dengan partisipasi politik masyarakat di Kecamatan Karenggede, Boyolali. Keberadaan mereka menjadi sangat penting. Tidak hanya untuk kepentingan peraihan suara, partisipasi tetapi juga untuk mensukseskan penyelenggaraan Pilgub Jateng 2008. Terlebih Pilgub kali ini adalah Pilgub kali pertama di Jateng yang diselenggarakan secara langsung dimana rakyat langsung memilih kandidat pilihannya, bukan melalui keterwakilan di lembaga legislatif (DPRD) seperti Pilgub sebelumnya. Pemilihan kepala daerah (Pilkada) langsung merupakan arus balik politik lokal atau sering disebut sebagai pergeseran dari sistem elite vote ke popular vote.

Berdasarkan latar belakang diatas, maka rumusan permasalahan yang akan dijawab adalah sebagai berikut;

1. Sejauhmana tingkat partisipasi politik masyarakat pedesaan di Kecamatan Karanggede, Boyolali 
dalam Pilgub Jateng 2008.

2. Sumber-sumber informasi dari mana saja yang mempengaruhi partisipasi politik masyarakat pedesaan di Kecamatan Karanggede, Boyolali dalam Pilgub Jateng 2008.

3. Faktor-faktor apa yang mempengaruhi dalam pengambilan keputusan memilih masyarakat pedesaan di Kecamatan Karanggede, Boyolali dalam Pilgub Jateng 2008.

4. Apakah ada hubungan signifikan antara sumber informasi dan latar belakang sosio-demografis yakni tingkat pendidikan, jenis pekerjaan dan tingkat penghasilan dengan partisipasi politik masyarakat pedesaan di Kecamatan Karanggede, Boyolali dalam Pilgub Jateng 2008.

\section{Timjauan Pustaka}

\section{Pemimpin Opini}

Seorang opinion leader biasanya mengacu pada seseorang yang mempunyai mempunyai tingkat pemahaman tinggi dan kebutuhan media tidak rendah. Melalui informasi dari merekalah (pemimpin opini) kadang perkembangan kontemporer diketahui masyarakat. Ini berarti, mereka secara tidak langsung menjadi perantara (bahkan penerjemah pesan) berbagai informasi yang diterima olehnya kemudian diteruskan kepada masyarakat. Mereka ini sangat dipercaya di samping juga jadi panutan, tempat bertanya dan meminta nasihat bagi anggota masyarakatnya (Nurudin, 2004 : 155-156).

Pemimpin opini dan pengikutnya biasanya sangat mirip dan menjadi bagian dari kelompok yang sama. Sangat tidak mungkin bahwa pemimpin opini akan sangat jauh dari pengikutnya dalam minat terhadap topik tertentu. Hubungan antarpribadi bukan hanya jaringan komunikasi tetapi juga merupakan sumber tekanan sosial untuk menyesuaikan diri kepada norma-norma kelompok dan sumber dukungan sosial untuk nilai-nilai dan opini yang dipercaya individu (Severin dan Tankard, 2005 : 244-245).

2. Partisipasi Politik

Menurut Verba Nie dan Kim dalam Affan Gaffar (1991 : 12) partisipasi politik adalah "legal activities by private citizens that are more or less directly aimed at influence the selection of govemmental personal andlor the actions they take". Miriam Budiardjo (1982 : 13) menyatakan partisipasi politik adalah kegiatan seseorang atau kelompok orang untuk ikut serta aktif dalam kehidupan politik yaitu dengan jalan memiliki pimpinan negara dan secara langsung atau tidak langsung mempengaruhi kebijaksanaan pemerintah.

Almond (1993) menyebut ada dua yaitu konvensional dan nonkonvensional. (1) Partisipasi politik konvensional adalah bentuk partisipasi politik yang normal dalam demokrasi modern. Termasuk di dalamnya pemberian suara (voting), diskusi politik, kegiatan kampanye, membentuk dan bergabung dalam kelompok kepentingan, komunikasi individual dengan pejabat politik dan administratif, (2) Partisipasi nonkonvensional termasuk di dalamnya pengajuan petisi, demonstrasi, konfrontasi, mogok, tindak kekerasan politik terhadap harta benda (perusakan, pengeboman, pembakaran), tindak kekerasan politik terhadap manusia (penculikan, pembunuhan) dan perang gerilya dan revolusi. Bentukbentuk dan frekuensi partisipasi politik dapat dipakai sebagai ukuran untuk menilai stabilitas sistem politik, integrasi kehidupan politik dan kepuasan atau ketidakpuasan warga negara. Pemberian suara (voting) 
merupakan bentuk partisipasi politik aktif yang paling luas tersebar.

\section{Komunikasi Politik}

Menurut Scudson (Karthubij, 2008:18) mendefinisikan komunikasi politik sebagai bentuk-bentuk pengiriman pesan yang dimaksudkan mempengaruhi distribusi atau penggunaan kekuasaan dalam masyarakat atau memiliki efek terhadap efek terhadap sikap dalam menggunakan kekuasaan.

Meadow (Pawito, 2007) mendefinisikan komunikasi politik sebagai "....any exchange of symbols or message that to a significant extent have been shaped bayor have consequences for the fuction of political systems." Denton dan Woodward (McNair, 1999) mengartikan komunikasi politik sebagai “...public discussion about the allocation of public resourches (revenues), official authority (who is given the power to make legal, legislative and executive decision) and official sanctions (what the state reward and punishes)." Dan Nimmo (1999 : 9) menyatakan komunikasi politik yaitu (kegiatan) komunikasi yang dianggap komunikasi politik berdasarkan konsekuensikonsekuensinya (aktual maupun potensial) yang mengatur perbuatan manusia di dalam kondisi-kondisi konflik.

Sementara agenda atau materi yang biasa dibahas dalam komunikasi politik yaitu analisis retorika, riset perubahan sikap, analisis propaganda, studi pemberian suara, studi berita media-pemerintah, analisis fungsi dan sistem serta perubahan teknologi (Karthubij, 2000 : 20-31).

Menurut Pawito (2007), komunikasi politik setidaknya memiliki enam unsur yaitu aktor atau partisipan, lambang-lambang pesan, saluran, proses, efek dan sistem politik dimana komunikasi politik berlangsung.

\section{Media Massa}

Pada hakikatnya, media adalah perpanjangan lidah dan tangan yang berjasa meningkatkan kapasitas manusia untuk mengembangkan struktur sosialnya (Rivers, Jensen dan Peterson, 2003 : 27). Istilah "media massa" pada umumnya dipakai untuk menunjuk alat-alat komunikasi massa seperti surat kabar, majalah, radio, televisi film, tape recorder, video dan cassete recorder. Akan tetapi lebih dari sekadar alat-alat teknologi seperti itu, media massa sebenarnya adalah juga merupakan suatu pranata sosial (social institution).

- Sebagai suatu pranata sosial, media massa menjalankan tugas apa yang oleh McQuail (dalam Pawito, 2007 : 258) diistilahkan sebagai silent characteristic yakni meliputi (a) penggunaan teknologi pembuatan dan penyebarluasan pesan-pesan secara massif, (b) organisasi dan regulasi yang bersifat sistematis, dan (c) arah pesan khalayak yang besar atau luas, tak diketahui secara personal (anonim) dan dan bebas dalam mengakses atau mengelak.

\section{Metode Penelitian}

1. Jenis dan Sumber Data

Penelitian dilakukan di wilayah Kecamatan Karanggede, Kabupaten Boyolali, Jawa Tengah (Jateng). Penggalian data di lokasi penelitian dilakukan selama tiga bulan sebelum, saat dan sesudah Pilgub Jateng 2008, 22 Juni 2008 yakni selama rentang Juni, Juli dan Agustus 2008.

Dilihat dari pendekatan metodologi riset, penelitian ini menekankan pada bentuk penelitian gabungan penelitian kuantitatif dengan 
penelitian kualitatif. Mengingat jenis penelitian ini termasuk multiple research strategies atau multiple methods, maka penelitian ini dilakukan dengan menggunakan metode survei, wawancara (interview) dan observasi.

Metode wawancara dalam penelitian ini dilakukan peneliti terhadap informan. Jumlah informan yang ditetapkan dalam penelitian ini sebanyak 19 orang terdiri dari pemilih yang memilih, pemilih yang tidak memilih (Golput), perangkat kecamatan, perangkat desa, panitia pemilihan kecamatan (PPK), panitia pengawas kecamatan (Panwascam), aktivis politik, tokoh masyarakat dan stakeholders terkait lain.

Sedangkan untuk teknik observasi nompartisan peneliti mengamati situasi dan kondisi saat aktivitas yang diteliti berlangsung yaitu kegiatan yang terkait partisipasi politik masyarakat pedesaan di Kecamatan Karanggede, Boyolali dalam Pilgub Jateng 2008. Selain observasi peristiwa yang diteliti, peneliti juga melakukan observasi pada dokumen serta arsiparsip (literatur) yang dibutuhkan dalam penelitian dari berbagai sumber.

\section{Populasi dan Sampel}

Populasi yang diambil adalah masyarakat pemilih di Kecamatan Karanggede, Boyolali dalam Pilgub Jateng 2008. Jumlah keseluruhan masyarakat pemilih atau daftar pemilih tetap (DPT) di Kecamatan Karanggede, Boyolali dalam Pilgub Jateng 2008 sebanyak 36.143 orang. Populasi terbagi dalam 16 desa dengan karakteristik yang cenderung sama (homogen).

Besarnya sampel yang ditetapkan sebanyak 75 orang yang dihitung menggunakan Rumus Slovin. Adapun rincian distribusi sampel di tiga lokasi desa penelitian didasarkan pada aspek pertimbangan keseimbangan atau pemerataan jumlah daftar pemilih tetap (DPT) di tiga desa lokasi penelitian bersangkutan dalam Pilgub Jateng 2008. Adapun rincian distribusi sampel penelitian ini adalah Desa Kebonan sebanyak 25 responden (DPT 2.721 orang), Desa Pengkol sebanyak 25 responden (DPT 3.024 orang) dan Desa Bangkok sebanyak 25 responden (DPT 1.883 orang).

3. Variabel

Dua variabel pokok dihadirkan dalam penelitian ini yakni sumber informasi (variabel independen) dan partisipasi politik (variabel dependen). Selain kedua variabel ini, dihadirkan juga variabel kontrol berupa latar belakang sosio-demografis yakni tingkat pendidikan, jenis pekerjaan dan tingkat penghasilan. Sementara hipotesis yang diajukan dalam penelitian ini adalah (a) ada hubungan signifikan antara sumber informasi dengan partisipasi politik, (b) ada hubungan signifikan antara tingkat pendidikan dengan partisipasi politik, (c) ada hubungan signifikan antara jenis pekerjaan dengan partisipasi politik, (d) ada hubungan signifikan antara tingkat penghasilan dengan partisipasi politik.

Variabel sumber informasi dalam penelitian ini dikategorikan dalam lima indikator sumber informasi yakni (a) tokoh masyarakat, (b) tetangga, (c) media massa, (d) partai politik dan (e) teman.

Variabel partisipasi politik dalam penelitian ini diukur dengan enam indikator yaitu (a) membicarakan (diskusi/ngobrol) dengan orang lain mengenai Pilgub Jateng 2008, (b) mengikuti kegiatan kampanye dalam Pilgub Jateng 2008, (c) mengajak orang lain mengikuti kegiatan kampanye dalam Pilgub Jateng 2008, (d) memberikan suara (mencoblos) dalam Pilgub Jateng 2008, (e) mengikuti 
kegiatan penghitungan suara dalam Pilgub Jateng 2008, (f) mengajak orang lain untuk mengikuti kegiatan penghitungan suara dalam Pilgub Jateng 2008.

Kemudian dibuatkan pengukuran jawaban yaitu 'Ya' (score 2) untuk tingkat partisipasi tinggi dan 'Tidak' (score 1) untuk tingkat partisipasi rendah. Dari nilai atau score jawaban ini selanjutnya ditetapkan dua pengelompokan untuk mengetahui tingkat partisipasi politik secara total yakni tingkat partisipasi politik tinggi (jika nilai atau score 9-12) dan tingkat partisipasi politik rendah (jika nilai atau score 6-8).

Variabel kontrol dalam penelitian ini terdiri dari tingkat pendidikan, jenis pekerjaan dan tingkat penghasilan. Variabel tingkat pendidikan ini diukur dengan empat indikator yaitu (a) lulus/tidak lulus SD/MI, (b) SMP/MTs, (c) SMA/MA/SMK dan (d) perguruan tinggi (Diploma, S1/S2/S3). Variabel jenis pekerjaan diukur dengan tiga indikator yaitu . (a) petani, (b) wiraswasta (pedagang, buruh, pemilik usaha mikro) dan (c) pegawai negeri sipil (PNS). Variabel tingkat penghasilan didasarkan atas penghasilan rata-rata perbulan pemilih sesuai jenis pekerjaannya sebagai petani, wiraswasta dan PNS dengan tiga indikator yaitu (a) kurang dari $\mathrm{Rp} 1$ juta/bulan, (b) $R p 1$ juta/bulan - Rp 1,5 juta/bulan dan (c) lebih dari Rp 1,5 juta/bulan.

Teknik analisis statistik ChiSquare/Chi Kuadrat (2-sided) digunakan untuk mengetahui apakah variabel dependen (sumber informasi) berkorelasi siginifikan dengan variabel independen (partisipasi politik). Juga, apakah variabel kontrol untuk kategori tingkat pendidikan dan jenis pekerjaan berkorelasi siginifikan dengan variabel independen (partisipasi politik), peneliti menggunakan teknik analisis statistik Chi-Square/Chi Kuadrat (2-sided). Sementara untuk mengetahui apakah variabel kontrol untuk kategori tingkat penghasilan berkorelasi siginifikan dengan partisipasi politik, peneliti menggunakan teknik analisis statistik analisis Pearson's Correlation (2tailed).

\section{Pembahasan}

\section{Partisipasi Politik}

a. Tingkat Partisipasi Politik

Secara umum bahwa masyarakat pedesaan di Kecamatan Karanggede, Boyolali memiliki tingkat partisipasi tergolong rendah dalam Pilgub Jateng 2008. Hal ini dibuktikan dari hasil analisis survei peneliti bahwa bahwa sebagian besar responden yakni 64 responden $\quad(85,3 \% \quad \mathrm{n}=75)$ memiliki tingkat partisipasi politik rendah dalam Pilgub Jateng 2008 (score 6-8). Hanya 11 responden atau $14,7 \%$ yang tergolong memiliki tingkat partisipasi tinggi dalam Pilgub Jateng 2008 (score 9-12).

Indikator partisipasi politik di sini terdiri dari enam aspek yaitu (a) membicarakan mengenai Pilgub Jateng 2008, (b) mengikuti kegiatan kampanye dalam Pilgub Jateng 2008, (c) mengajak orang lain mengikuti kegiatan kampanye dalam Pilgub Jateng 2008, (d) memberikan suara (mencoblos) dalam Pilgub Jateng 2008, (e) mengikuti penghitungan suara dalam Pilgub Jateng 2008 dan (f) mengajak orang lain mengikuti kegiatan penghitungan suara dalam Pilgub Jateng 2008).

Berdasarkan hasil survei dan wawancara di lapangan, rendahnya partisipasi politik masyarakat pedesaan di Kecamatan Karanggede, Boyolali dalam Pilgub Jateng 2008 secara umum disebabkan dua hal utama yaitu (1) rasa jenuh dengan Pemilu (faktor 
psikologis), (2) masyarakat lebih mementingkan pekerjaan (faktor ekonomis). Rasa jenuh dengan Pemilu dikarenakan terlalu seringnya penyelenggaraan Pemilu baik tingkat pusat maupun tingkat daerah. Selain itu, hasil Pemilu selama ini dinilai belum/tidak sesuai harapan masyarakat yakni belum/tidak adanya perubahan yang berarti terutama perubahan di sektor perekonomian, kesehatan, pendidikan dan lapangan kerja di masyarakat. Selain itu, sebagian masyarakat lebih mementingkan bekerja daripada mengurusi Pilgub sehingga mereka tidak memilih (Golput). Tindakan Golput ini terutama dilakukan masyarakat yang sedang merantau ke luar daerah (boro).

b. Memberikan Suara (Voting)

Sementara itu, dari enam indikator partisipasi politik yang ditetapkan, hanya satu indikator yang memiliki nilai partisipasi politik tinggi yakni pemberian suara (voting) dalam Pilgub Jateng 2008 ( 72 responden atau $96,0 \% ; \quad n=75$ ). Sedangkan lima indikator partisipasi politik lainnya (diskusi, kampanye, mengajak kampanye, mengikuti perhitungan suara dan mengajak mengikuti perhitungan suara) menunjukkan kondisi sebaliknya yakni memiliki nilai partisipasi rendah (rata-rata kurang dari $10 \% ; n=75$ ).

Tingginya angka pemberian suara (voting) ini bersesuaian dengan hasil rekapitulasi pemungutan suara Pilgub Jateng 2008 di Kecamatan Karanggede, Boyolali bahwa dari daftar pemilih tetap (DPT) 36.143 jiwa, sebanyak 19.249 jiwa atau $53,26 \%$ menggunakan hak pilihnya. Alasan responden sendiri menggunakan hak pilihnya dalam Pilgub Jateng 2008 karena dipengaruhi tiga faktor utama yaitu (1) menunaikan hak sebagai warga negara yang baik; (2) ingin mendapatkan pemimpin yang bisa merubah keadaan lebih baik (efikasi politik), (3) sebagai momen rutinitas. (Golput)

c. Tidak Memberikan Suara Meski mayoritas pemilih menggunakan haknya $(53,26 \%)$, namun angka pemilih tidak memilih (golongan putih atau Golput) di Kecamatan Karanggede, Boyolali dalam Pilgub Jateng 2008 tergolong tinggi yaitu 16.896 jiwa atau $46,74 \%$ dari DPT 36.143 jiwa walaupun hasil survei peneliti hanya menemukan 3 responden atau $4.0 \%$ yang Golput. Tingginya angka Golput di Karanggede ini disebabkan tiga hal utama yaitu (1) merantau bekerja ke luar daerah atau boro (faktor ekonomi); (2) tidak optimalnya pemutakhiran data pemilih (faktor teknis); (3) rasa jenuh karena menurunnya tingkat kepercayaan terhadap pemerintah dan partai politik (faktor psikologis yakni sinisme politik atau alienasi politik).

\section{Sumber-Sumber Informasi}

Berdasarkan hasil survei peneliti, tokoh masyarakat merupakan sumber informasi yang mempengaruhi partisipasi politik sampai tingkat tertentu sebagian besar (mayoritas) masyarakat pedesaan di Kecamatan Karanggede, Boyolali dalam Pilgub Jateng 2008 (31 responden atau 41,3\%; $\mathrm{n}=75$ ), disusul tetangga (26 responden atau $34,7 \%)$, media massa (12 responden atau $16,0 \%$ ), partai politik (1 responden atau $1,3 \%$ ) dan teman (1 responden atau $1,3 \%$ ).

a. Tokoh Masyarakat

Hasil penelitian ini menunjukkan tokoh masyarakat merupakan sumber informasi paling berpengaruh terhadap partisipasi politik mayoritas masyarakat pedesaan di Kecamatan Karanggede, Boyolali dalam Pilgub Jateng 2008. Hal ini menandakan masih kuatnya pengaruh 
pemuka pendapat (opinion leader) di wilayah tersebut. Hal ini juga mengindikasikan masih kuatnya jenis komunikasi interpersonal atau lebih khas dengan istilah gethok tular di Kecamatan Karanggede, Boyolali.

Jenis pemuka pendapat yang lebih banyak berpengaruh pada partisipasi politik masyarakat pedesaan di Kecamatan Karanggede, Boyolali dalam Pilgub Jateng 2008 adalah pemuka pendapat struktural yakni pemuka pendapat yang memiliki jabatan formal di masyarakat seperti aparatur kecamatan, aparatur desa, pengurus badan permusyawaratan desa (BPD), pengurus rukun tetangga (RT) dan pengurus rukun warga (RW). Selain memiliki nama (reputasi) luas, para pemuka pendapat struktural ini juga memiliki peran lebih menonjol di masyarakat dibanding pemuka pendapat kultural seperti tokoh agama, tokoh pendidikan, tokoh budaya, tokoh politik dan lainnya.

Pengaruh tokoh masyarakat di Kecamatan Karanggede, Boyolali dalam Pilgub Jateng 2008 lebih bersifat persuasif-konstruktif - seperti mensosialisasikan aturan-aturan dalam Pilgub Jateng 2008, mengajak pemilih agar tidak Golput dan lainnya. Pengaruh tokoh masyarakat di sini tidak bersifat persuasif non-konstruktif seperti menganjurkan agar memilih pasangan kandidat tertentu, mengajak Golput, mengajak agar mengikuti kampanye dan lainnya.

Sementara itu, jika secara umum tingkat partisipasi politik pemilih di Kecamatan Karanggede, Boyolali dalam Pilgub Jateng 2008 tergolong rendah $(85,3 \% \mathrm{n}=75)$, maka hal ini bukan sepenuhnya karena pengaruh pemuka pendapat (tokoh masyarakat sebagai sumber informasi utama) melainkan lebih karena pengaruh internal pemilih sendiri seperti yang disebutkan sebelumnya yaitu (1) rasa jenuh dengan Pemilu (faktor psikologis); (2) lebih mementingkan pekerjaan (faktor ekonomis).

b. Tetangga

Tetangga merupakan sumber informasi yang memiliki pengaruh cukup tinggi sampai tingkat tertentu terhadap partisipasi masyarakat pedesaan di Kecamatan Karanggede, Boyolali dalam Pilgub Jateng 2008 (26 responden atau $34,7 \%, n=75$ ). Hal ini juga menandakan masih kuatnya jenis komunikasi interpersonal baik komunikasi diadik (dua orang) maupun komunikasi kelompok kecil (lebih dari dua orang).

\section{c. Media Massa}

Media massa juga merupakan sumber informasi yang memiliki cukup pengaruh sampai tingkat tertentu terhadap partisipasi politik masyarakat pedesaan di Kecamatan Karanggede, Boyolali dalam Pilgub Jateng 2008 (12 responden atau $16,0 \%$ ). Hal ini menandakan adanya terpaan media (media exposure) kepada pemilih sampai derajat tertentu di Kecamatan Karanggede, Boyolali dalam Pilgub Jateng 2008. Hal ini juga menguatkan eksistensi fungsi media massa sebagai pengawasan lingkungan (surveillance) yakni memberi informasi dan menyediakan berita, korelasi (correlation) dan penyampaian warisan sosial (transmission of the social heritage) (Harold Lasswell, 1960). Meski demikian keberadaannya belum sebagai pilihan utama di masyarakat.

Sementara, jenis media massa yang paling sering diakses masyarakat pedesaan di Kecamatan Karanggede, Boyolali adalah televisi (36 responden atau $48,0 \%, n=75)$, surat kabar $(17$ responden atau $22,6 \%$ ) dan radio (2 responden atau 2,7\%). Data ini menunjukkan bahwa televisi pada saat ini telah menjadi media keluarga dan 
bukan menjadi barang mewah (langka) lagi bagi masyarakat pedesaan.

c. Partai Politik

Partai politik merupakan sumber informasi yang juga berpengaruh sampai tingkat tertentu terhadap partisipasi politik masyarakat pedesaan di Kecamatan Karanggede, Boyolali dalam Pilgub Jateng 2008. Meski demikian derajat pengaruhnya tersebut tergolong rendah (1 responden atau $1,3 \% ; n=75$ ). Hal ini dipengaruhi dua sebab utama yaitu (a) tingkat kepercayaan masyarakaî terhadap partai politik saat ini cenderung menurun (rendah); (b) kinerja mesin partai politik dalam mempersuasi masyarakat kurang/tidak optimal.

d. Teman

Teman sebagai sumber informasi yang berpengaruh sampai tingkat tertentu terhadap partisipasi politik masyarakat pedesaan di Kecamatan Karanggede, Boyolali dalam Pilgub Jateng 2008. Sama seperti partai politik, derajat pengaruh teman di sini juga tergolong rendah ( 1 responden atau $1,3 \%$; $n=75)$. Meski derajat pengaruhnya rendah, namun data ini menunjukkan keberadaan (eksistensi) jenis komunikasi diadik dalam ajang Pilgub Jateng 2008.

\section{Keputusan Memilih}

\section{a. Ideologi}

Sampai tingkat tertentu, faktor ideologi (partai politik pengusung kandidat) merupakan faktor yang mempengaruhi keputusan memilih mayoritas masyarakat pedesaan di Kecamatan Karanggede, Boyolali dalam Pilgub Jateng 2008 (24 responden atau $32,0 \% ; n=75)$. Selanjutnya penampilan kandidat (19 responden atau $25,3 \%$ ), isu kampanye/program kerja kandidat (16 responden atau $21,3 \%$ ) dan karakter dan track record kandidat (13 responden atau $17,4 \%$ ).
Hasil rekapitulasi perolehan suara Pilgub Jateng 2008 di Kecamatan Karanggede, Boyolali dimenangkan Bibit Waluyo-Rustriningsih (7.006 suara atau $36,39 \%$; $n=19.250$ pemilih), Bambang Sadono-Muh Adnan dari Partai Golkar (PG) (5.942 suara atau $30,8 \%$ ), Sukawi Sutarip-Sudharto dari Partai Demokrat (PD) dan Partai Keadilan Sejahtera (PKS) (2.317 suara atau 12,03\%), Muh Tamzil-Abdul Rozaq Rais dari Partai Persatuan Pembangunan (PPP) dan Partai Amanat Nasional (PAN) (1.813 suara atau 9,4\%) dan Agus Soeyitno-Abdul Kholiq Arif dari Partai Kebangkitan Bangsa (PKB) pro $\mathrm{KH}$ Abdurrahman Wahid (Gus Dur) (1.290 suara atau 6,7\%).

Kemenangan Bibit WaluyoRustriningsih (PDIP) dalam Pilgub Jateng 2008 (39\%) disusul Bambang Sadono-Muh Adnan (PG) non PD yang memperoleh suara suara signifikan $(30,8 \%)$ sebagai tanda bahwa ideologi partai politik nasionalis mendominasi masyarakat pedesaan di Kecamatan Karanggede, Boyolali. Total perolehan suara PDIP dan PG dalam Pilgub Jateng 2008 mencapai 12.948 suara atau $67,19 \%$. Temuan penelitian ini meneguhkan persepsi politis bahwa Jawa Tengah memang menjadi salah satu kandang (basis) partai-partai politik berhaluan nasionalis (abangan).

Sementara partai politik berideologi berbasis religius (PPP dan PKS) dan partai politik berideologi berbasis nasionalis-religius (PAN dan PKB pro KH Abdurrahman Wahid (Gus Dur)) kurang mendapatkan pengaruh di masyarakat pedesaan di Kecamatan Karanggede, Boyolali dalam Pilgub Jateng 2008. Hal ini dibuktikan dari hasil perolehan suara dimana suara PKS plus PD (12,03\%), suara PPP dan PAN $(9,4 \%)$ dan suara $\mathrm{PKB}$ pro $\mathrm{KH}$ Abdurrahman Wahid (Gus Dur) (6,7\%). Total perolehan suara PKS, PPP, PAN, 
PKB pro KH Abdurrahman Wahid (Gus Dur) ditambah PD (partai berideologi nasionalis) dalam Pilgub Jateng 2008 hanya mencapai 5.420 suara atau $32,81 \%$.

b. Penampilan Kandidat

Umumnya masyarakat pedesaan di Kecamatan Karanggede, Boyolali dalam Pilgub Jateng 2008 memilih Cagub dan Cawagub dengan penampilan low profile, merakyat, citra berpihak pada "wong ndesa", usia relatif masih muda dan peka gender.

c. Isu Kampanye/Program Kerja Kandidat

Umumnya juga bahwa masyarakat pedesaan di Kecamatan Karanggede, Boyolali dalam Pilgub Jateng 2008 cenderung pada isu kampanye/program kerja kandidat yang konkret dan langsung menyentuh kepentingan rakyat seperti kesejahteraan, pendidikan, kesehatan dan pengangguran. Isu-isu kampanye yang ada diharapkan tidak sekadar isapan jempol artinya dilupakan kandidat setelah terpilih seperti yang selama ini terjadi.

Kandidat

d. Karakter dan Track Record Selain itu, secara umum bahwa masyarakat pedesaan di Kecamatan Karanggede, Boyolali dalam Pilgub Jateng 2008 memilih sosok kandidat dengan karakter dan track record tegas, tenang, punya rekam jejak moralitas baik, profesional, punya pengalaman memimpin organisasi/birokrasi, tidak pernah tersangkut kasus hukum terutama korupsi, banyak bekerja untuk kepentingan rakyat serta bisa memberi rasa aman.

e. Marketing Politik

Faktor-faktor yang berpengaruh terhadap keputusan memilih masyarakat pedesaan di Kecamatan Karanggede, Boyolali dalam Pilgub Jateng 2008 (karakter dan track record kandidat, ideologi (partai pengusung kandidat), isu kampanye / program kerja kandidat dan penampilan kandidat) tidaklah berdiri sendiri melainkan dipengaruhi oleh pengemasan faktor-faktor tersebut melalui strategi marketing politik.

Dalam konteks Pilgub Jateng 2008, kandidat dan tim suksesnya menggunakan kampanye sebagai strategi marketing politik baik langsung (kampanye terbuka dan kampanye dialogis) maupun kampanye tidak langsung (menggunakan media konvensional dan media nonkonvensional). Media konvensional seperti spanduk, baliho, banner, bendera dan stiker. Media nonkonvensional seperti iklan politik di media massa (koran, televisi dan radio).

\section{Variabel-Variabel Berpengaruh}

Berdasarkan hasil analisis penelitian, hipotesis dalam penelitian ini diterima bahwa ada hubungan signifikan antara variabel sumber informasi dengan variabel partisipasi politik dalam Pilgub Jateng 2008 (nilai hitung Chi-Square sebesar 10,650 dengan derajat kebebasan (df) 5 dan taraf signifikansi 0,059 yang kurang dari $5 \%$ ). Artinya, sumber informasi (tokoh masyarakat, tetangga, media massa, partai politik dan teman) mempunyai hubungan yang menghasilkan pengaruh dengan partisipasi politik masyarakat pedesaan di Kecamatan Karanggede, Boyolali dalam Pilgub Jateng 2008. Data ini menunjukkan adanya kecenderungan bahwa semakin terpercaya sumbersumber informasi yang diakses pemilih, maka semakin tinggi (kuat) pula pengaruh sumber-sumber informasi bersangkutan terhadap partisipasi politik mereka. Sebaliknya, ada kecenderungan bahwa semakin kurang/tidak terpercaya sumber-sumber informasi yang diakses pemilih, maka 
semakin rendah pula pengaruh sumbersumber informasi bersangkutan terhadap partisipasi politik mereka.

Hipotesis dalam penelitian ini diterima bahwa ada hubungan signifikan antara variabel tingkat pendidikan dengan variabel partisipasi politik dalam Pilgub Jateng 2008 (nilai hitung Chi-Square sebesar 15,738 dengan derajat kebebasan (df) 4 dan taraf signifikansi 0,003 yang kurang dari $5 \%$ ). Artinya, tingkat pendidikan (SD/MI (lulus/tidak lulus), SMP/MTs, SMA/MA/SMK, Perguruan Tinggi (Diploma/S1/S2/S3)) mempunyai hubungan yang menghasilkan pengaruh dengan partisipasi politik masyarakat pedesaan di Kecamatan Karanggede, Boyolali dalam Pilgub Jateng 2008. Data ini juga menunjukkan kecenderungan bahwa semakin rendah tingkat pendidikan pemilih, maka semakin rendah pula tingkat keterlibatan mereka dalam partisipasi politik. Sebaliknya, ada kecenderungan bahwa semakin tinggi tingkat pendidikan pemilih, maka semakin tinggi pula tingkat keterlibatan mereka dalam partisipasi politik.

Hipotesis dalam penelitian ini diterima bahwa ada hubungan signifikan antara variabel jenis pekerjaan dengan variabel partisipasi politik dalam Pilgub Jateng 2008 (nilai hitung Chi-Square sebesar 13,905 dengan derajat kebebasan (df) 2 dan taraf signifikansi 0,001 yang kurang dari 5\%). Artinya, jenis pekerjaan (petani, PNS dan pegawai swasta) mempunyai hubungan yang menghasilkan pengaruh dengan partisipasi politik masyarakat pedesaan di Kecamatan Karanggede, Boyolali dalam Pilgub Jateng 2008. Data ini juga menunjukkan kecenderungan bahwa semakin tinggi status sosial pekerjaan pemilih, maka semakin tinggi pula tingkat keterlibatan mereka dalam partisipasi politik. Sebaliknya ada kecenderungan bahwa semakin rendah status sosial pekerjaan pemilih, maka semakin rendah pula tingkat keterlibatan mereka dalam partisipasi politik.

Hipotesis dalam penelitian ini diterima bahwa ada hubungan signifikan antara variabel tingkat penghasilan dengan variabel partisipasi politik dalam Pilgub Jateng 2008 (nilai hitung Pearson's Correlation sebesar 0,301 dengan derajat kebebasan (df) 4 dan taraf signifikansi 0,009 yang kurang dari $5 \%$ ). Artinya, tingkat penghasilan (sebagai petani, PNS dan pegawai swasta) mempunyai hubungan yang menghasilkan pengaruh dengan partisipasi politik masyarakat pedesaan di Kecamatan Karanggede, Boyolali dalam Pilgub Jateng 2008. Data ini juga memiliki kecenderungan bahwa semakin tinggi tingkat penghasilan pemilih, maka semakin tinggi pula tingkat keterlibatan mereka dalam partisipasi politik. Sebaliknya ada kecenderungan bahwa semakin rendah tingkat penghasilan pemilih, maka semakin rendah pula tingkat keterlibatan mereka dalam partisipasi politik.

\section{Kesimpulan}

Dari uraian di atas, beberapa hal yang dapat disimpulkan antara lain :

1. Masyarakat pedesaan di Kecamatan Karanggede, Boyolali memiliki tingkat partisipasi tergolong rendah dalam Pilgub Jateng 2008 dilihat dari enam indikator yaitu mendiskusikan Pilgub, mengikuti kampanye,) mengajak orang lain agar mengikuti kampanye, memberikan suara, mengikuti penghitungan suara, dan mengajak orang lain agar mengikuti 
penghitungan suara).

2. Rendahnya partisipasi politik masyarakat pedesaan di Kecamatan Karanggede, Boyolali dalam Pilgub Jateng 2008 secara umum disebabkan dua hal utama yaitu (1) rasa jenuh dengan Pemilu (faktor psikologis); (2) lebih mementingkan pekerjaan (faktor ekonomis).

3. Angka pemilih tidak memilih (golongan putih atau Golput) di Kecamatan Karanggede, Boyolali dalam Pilgub Jateng 2008 tergolong tinggi yaitu 16.896 jiwa atau $46,74 \%$ dari DPT 36.143 jiwa Tingginya angka Golput ini disebabkan tiga hal utama yaitu (1) merantau bekerja ke luar daerah (faktor ekonomi); (2) tidak optimalnya pemutakhiran data pemilih (faktor teknis); (3) rasa jenuh karena menurunnya tingkat kepercayaan terhadap pemerintah dan partai politik (faktor psikologis yakni sinisme politik atau alienasi politik).

4. Tokoh masyarakat merupakan sumber informasi yang mempengaruhi partisipasi politik sampai tingkat tertentu mayoritas masyarakat pedesaan di Kecamatan Karanggede, Boyolali dalam Pilgub Jateng 2008. Pengaruh tokoh masyarakat di sini lebih bersifat persuasif-konstruktif seperti mensosialisasikan aturan-aturan dalam Pilgub Jateng 2008, mengajak pemilih agar tidak Golput dan lainnya.

5. Faktor ideologi (partai politik pengusung kandidat) merupakan faktor yang mempengaruhi keputusan memilih mayoritas masyarakat pedesaan di
Kecamatan Karanggede, Boyolali dalam Pilgub Jateng 2008. Meski demikian, faktor terkait tidak berdiri sendiri melainkan juga didukung faktor lain seperti strategi marketing politik. Bahwa partai politik beraliran ideologi nasionalis seperti PDIP dan Partai Golkar (PG) non Partai Demokrat (PD) mendapatkan pengaruh lebih kuat di Karanggede dibanding partai politik beraliran ideologi religius (PKS dan PPP) dan nasionalis-religius (PKB pro $\mathrm{KH}$ Abdurrahman Wahid (Gus Dur) dan PAN).

6. Ada kecenderungan semakin terpercaya sumber-sumber informasi yang diakses pemilih, maka semakin tinggi (kuat) pula pengaruh sumber-sumber informasi bersangkutan terhadap partisipasi politik mereka. Sebaliknya, ada kecenderungan bahwa semakin kurang/tidak terpercaya sumber-sumber informasi yang diakses pemilih, maka semakin rendah pula pengaruh sumber-sumber informasi bersangkutan terhadap partisipasi politik mereka.

7. Ada kecenderungan bahwa semakin rendah tingkat pendidikan pemilih, maka semakin rendah pula tingkat keterlibatan mereka dalam partisipasi politik. Sebaliknya, ada kecenderungan bahwa semakin tinggi tingkat pendidikan pemilih, maka semakin tinggi pula tingkat keterlibatan mereka dalam partisipasi politik.

8. Ada kecenderungan semakin tinggi status sosial pekerjaan pemilih, maka semakin tinggi pula tingkat keterlibatan mereka 
dalam partisipasi politik. Sebaliknya ada kecenderungan bahwa semakin rendah status sosial pekerjaan pemilih, maka semakin rendah pula tingkat keterlibatan mereka dalam partisipasi politik.

9. Ada kecenderungan bahwa semakin tinggi tingkat penghasilan pemilih, maka semakin tinggi pula tingkat keterlibatan mereka dalam partisipasi politik. Sebaliknya ada kecenderungan bahwa semakin rendah tingkat penghasilan pemilih, maka semakin rendah pula tingkat keterlibatan mereka dalam partisipasi politik.

\section{Daftar Pustaka}

Budiarjo, Miriam, 2008. Dasar-Dasar Ilmu Politik. Edisi Revisi Cetakan Ke-2. Jakarta. Ikrar Mandiriabadi.

Budiarjo, Miriam, dkk. 1998. Partisipasi dan Partai Politik: Sebuah Bungai Rampai. Jakarta. Yayasan Obor Indonesia.

Karthubij, Susanto. 2000. Komunikasi Politik: Pengantar Wacana. Surakarta. Jurusan Ilmu Komunikasi Universitas Sebelas Maret.

Nurudin. 2004. Sistem Komunikasi Indonesia. Cetakan Ke-1. Jakarta. Raja Grafindo Persada.

Pawito. 2007. Penelitian Komunikasi Kualitatif. Cetakan Ke-1. Yogyarakta. LKiS Pelangi Aksara.

Severin, Werner J., dan James W Tankard. 2005. Teori Komunikasi Sejarah, Metode dan Terapan di dalam Media Massa. Cetakan Ke-5. Terj. Sugeng Hariyanto. Jakarta. Prenada Media. 